JURNAL REKA YASA PROSES
Volume 10 No.2, 2016, hal. 55-63
Journal homepage: http://journal.ugm.ac.id/jrekpros

\title{
Produksi Organic Preservative dan Solid Biofuel dari Hydrothermal Treatment Tongkol Jagung dengan Variasi Temperatur
}

Haidar Ali* dan Ahmad Tawfiequrrahman Yuliansyah

Departemen Teknik Kimia, Fakultas Teknik, Universitas Gadjah Mada

Jl Grafika No. 2 Kampus UGM, Yogyakarta, 55281

*Alamat korespondensi: haidar.ali@mail.ugm.ac.id

\section{A B S T RA C T}

Corn is one of staple food and influential commodity driving Indonesia's economy. Indonesia currently produces as high as 19 million tons of corn which contains 50\% of biomass in the form of cob. Waste from harvesting and consumption of corn, namely, corn cob $(C C)$ is left as waste. This CC is actually a sustainable, easily accessible, and renewable biomass energy source as an alternative to Indonesia's depleting fossil fuel reserves. Hydrothermal treatment is a conversion method that has some consequential advantages compared to other methods; e.g. the ability to treat high-moisture biomass like CC and the possibility to use lower temperature. This research aims to produce and characterize liquid and solid fuel subsequent to hydrothermal treatment of CC obtained from Sleman, Yogyakarta. After size reduction, fine particles were mixed with water to form slurry. Slurry was heated in an autoclave for hydrothermal treatment at initial pressure of $2.0 \mathrm{MPa}$ and was held for $200^{\circ} \mathrm{C}, 240^{\circ} \mathrm{C}$, and $270^{\circ} \mathrm{C}$ in 30 minutes. The solid and liquid products were then separated. Liquid was analyzed using GC-MS and solid by using AAS. The result showed that, in comparison to raw material, solid product had higher carbon content which resulted in the increase of calorific value of the solid biofuel. The calorific value of solid product ranged from 19,59 -22,02 MJ/kg or 20,93$35,87 \%$ higher than raw materials and 4-17\% higher than average coal used in Indonesia. Major component in liquid product are $N, N$-dimethyl formamide, furfural, and phenolic compound, with benzoic acid present as minor component. The potential of liquid products as organic preservatives are examined by testing the tenacity of wood against termite according to ASTM D3345-74 standard method. Result showed that liquid product were effective in exhibiting termiticidal activity and temperature $200^{\circ} \mathrm{C}$ showed the optimum condition.

Keywords: corn cob, hydrothermal treatment, organic preservatives, solid biofuel.

\section{A B S T R A K}

Jagung merupakan salah satu makanan pokok dan komoditas yang berpengaruh terhadap ekonomi Indonesia. Produksi jagung Indonesia saat ini mencapai 19 juta ton dan sebanyak 50\% berupa tongkol. Limbah dari pemanenan dan konsumsi jagung adalah tongkol jagung (CC) yang cepat busuk dan banyak kelemahannya yang harus ditangani. Sebetulnya, CC merupakan solusi yang berkelanjutan, mudah diperoleh, serta sumber energi terbarukan berupa biomassa yang dapat menjadi alternatif solusi untuk berkurangnya cadangan bahan bakar fosil di Indonesia. Hydrothermal treatment adalah metode konversi yang memiliki beberapa keunggulan jika dibandingkan dengan metode lain seperti 
kemampuan untuk menangani kandungan air yang tinggi pada $\mathrm{CC}$ dan kemungkinan penggunaan temperatur yang rendah. Penelitian ini bertujuan untuk mengkarakterisasi cairan dan padatan yang dihasilkan dari proses hydrothermal terhadap tongkol jagung yang diperoleh dari Sleman, Yogyakarta. Setelah proses reduksi ukuran, partikel halus tersebut dicampur dengan air sehingga terbentuk slurry. Slurry dipanaskan dalam autoclave untuk dijalankan proses hydrothermal dengan tekanan awal sebesar 2.0 MPa dan dijalankan pada suhu $200^{\circ} \mathrm{C}, 240^{\circ} \mathrm{C}$, dan $270^{\circ} \mathrm{C}$ dengan holding time selama 30 menit. Padatan dan cairan yang dihasilkan dipisahkan. Cairan dianalisis dengan GC-MS sedangkan padatan dengan AAS. Hasil menunjukkan bahwa dengan perbandingan bahan baku, padatan memiliki kandungan karbon yang lebih tinggi sehingga terjadi kenaikan nilai kalor. Nilai kalor padatan berkisar antara 19,59-22,02 MJ/kg atau 20,93-35,87\% lebih tinggi dari bahan baku dan 4-17\% dari batubara yang ada saat ini. Cairan yang dihasilkan didominasi oleh $N, N$-dimethyl formamide, furfural, phenolic compound serta sedikit asam berupa benzoic acid. Pengujian produk cairan sebagai pengawet organik dilakukan dengan pengujian ketahanan kayu terhadap rayap sesuai dengan standar ASTM D3345-74. Hasil menunjukkan bahwa cairan yang dihasilkan cukup efektif sebagai pembunuh rayap dan variasi temperatur $200^{\circ} \mathrm{C}$ memberikan kondisi yang optimum.

Kata kunci: tongkol jagung, proses hidrotermal, pengawet organik, bahan bakar padat.

\section{Pendahuluan}

Indonesia sebagai negara agraris memiliki berbagai varian tanaman yang sangat melimpah. Salah satu limbah agrikultura yang dapat dijadikan sumber biomassa adalah tongkol jagung (corn cob). Berdasarkan Badan Pusat Statistik (BPS), jumlah produksi jagung pada tahun 2015 adalah 19.612.435 ton/tahun. Dengan 40\%-50\% berupa tongkol jagung (Richana, 2010), sehingga jumlah tongkol jagung yang dihasilkan sebanyak 9.806.217,5 ton/tahun. Upaya meningkatkan kualitas biomassa dapat dilakukan dengan mengkonversi biomassa menjadi bahan bakar yang memiliki nilai kalor lebih tinggi. Menurut Child (2014) berbagai metode telah banyak dikembangkan antara lain pembakaran langsung, pirolisis dan gasifikasi namun memiliki beberapa kelemahan yaitu antara lain membutuhkan suhu yang lebih tinggi serta kadar air pada biomassa yang akan diolah sering mengurangi efisiensi termal. Oleh karena itu, diperlukan biaya tambahan dalam pengeringan biomassa tersebut. Upgrading biomassa dengan hydrothermal treatment lebih diminati karena dapat menghasilkan solid fuel, dapat dijalankan pada suhu operasi yang lebih rendah, serta lebih efektif untuk mengolah biomassa dengan kadar air yang tinggi seperti limbah agrikultura yang memiliki kandungan air lebih dari $50 \%$ berat (Yuliansyah dkk, 2010). Produk padatan yang dihasilkan dapat digunakan untuk berbagai keperluan industri seperti bahan bakar furnace, pembangkit listrik dan pembangkit steam (Obernberger dkk, 2006).

Dalam aspek yang lain, kebutuhan kayu untuk bahan konstruksi semakin meningkat sedangkan persediaan kayu high quality di alam semakin menurun. Upaya untuk mengatasi hal tersebut, dilakukan perencanaan program Hutan Tanaman Industri (HTI) yang ditanami dengan kayu cepat tumbuh atau fast growing species, namun jenis kayu tersebut memiliki keawetan rendah (FAO, 2010). Selain program tersebut, pengawetan kayu menjadi salah satu pilihan yang dirasa dapat menjadi solusi permasalahan tersebut. Terdapat beragam pengawet yang digunakan saat ini, namun bahan pengawet tersebut umumnya toxic. Di sisi lain, pengawet yang ada merupakan pengawet sintesis anorganik sehingga bersifat non-biodegradable. Dengan demikian, diperlukan bahan pengawet yang bersifat ramah lingkungan.

Pengawet organik yang banyak beredar saat ini adalah turunan pyroligneous acid namun ketersediaannya masih terbatas. Oleh karena itu, diperlukan alternatif pengawet organik yang tepat. Adapun syarat biomassa yang dapat menghasilkan pengawet yang efektif harus memiliki kandungan selulosa, hemiselulosa, serta lignin yang tinggi. Menurut Yuniningsih (2014) tingginya kandungan bahan-bahan tersebut dapat menghasilkan asam-asam organik yang berfungsi 
sebagai anti-microbial. Selain itu, kandungan lignin dapat terurai menjadi fenol yang dapat mencegah oksidasi lemak serta menghambat pembentukan radikal bebas. Indikator lain keberhasilan bahan pengawet adalah $\mathrm{pH}$ yang menjadi acuan ketahanan hidup jasad renik, karena pada rentang $\mathrm{pH}$ tertentu dapat menghambat pertumbuhan mikrobia (Yatagai, M. dkk, 2004). Berdasarkan data yang ada, spesifikasi cairan hasil hydrothermal treatment menjadi salah satu kandidat pengawet organik.

Dengan potensi tersebut, penelitian ini perlu dilakukan dalam rangka pengujian keberhasilan produk cair hydrothermal treatment ini sebagai pengawet organik. Tujuan penelitian ini adalah mengkarakterisasi produk padat yang dihasilkan, mengetahui komponen penyusun produk cair serta menguji produk cair sebagai pengawet organik kayu terhadap rayap.

\section{Metode Penelitian}

\subsection{Bahan Penelitian}

Bahan utama yang digunakan dalam penelitian ini adalah tongkol jagung yang diperoleh dari Kabupaten Sleman, Daerah Istimewa Yogyakarta. Sebagai bahan untuk uji pengawetan kayu, digunakan kayu bangkirai (Shorea lavevolia Endent) yang diperoleh dari Kabupaten Sleman, Daerah Istimewa Yogyakarta. Rayap yang digunakan untuk pengujian termiticidal activity produk cair hydrothermal treatment adalah rayap jenis Cryptotermes. Spp. yang diperoleh dari Pusat Penelitian dan Pengembangan Perhutani Cepu, Kabupaten Bojonegoro, Jawa Tengah.

\subsection{Alat Penelitian}

Rangkaian alat penelitian disajikan pada Gambar 1. Bagian utama alat ini adalah autoclave tipe batch (Autoclave Engineers Part Number HT-A13989) yang dilengkapi dengan pengaduk dan temperature controller.

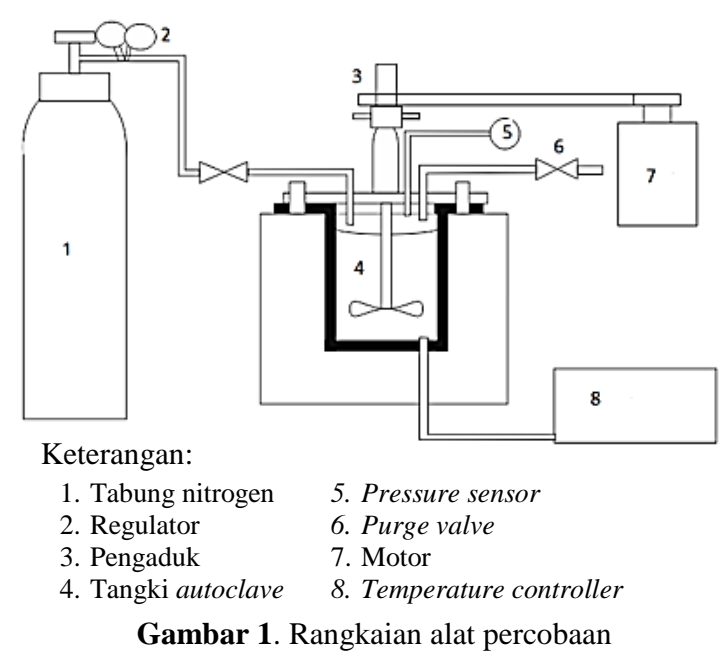

\subsection{Cara Penelitian}

2.3.1 Tahap Kalibrasi Suhu pada Autoclave

Air sebanyak $100 \mathrm{~mL}$ dimasukkan ke dalam autoclave. Termometer raksa digantung pada statif sehingga ujung termometer tercelup pada air di dalam autoclave. Pemanas dan controller dinyalakan. Suhu yang terbaca pada termometer raksa dan suhu pada controller dicatat.

\subsubsection{Tahap Preparasi Bahan Baku}

Tongkol jagung dipotong kecil-kecil kemudian dihaluskan dengan menggunakan grinder. Bahan yang telah halus diayak menggunakan ayakan Tyler 20 dan 32 Mesh, sehingga diperoleh sampel tongkol jagung dengan ukuran $-20+32$ Mesh.

\subsubsection{Tahap Proses Hydrothermal}

Tongkol jagung berukuran -20+32Mesh ditimbang sebanyak 15 gram dan dicampur dengan $150 \mathrm{~mL}$ akuades. Campuran tersebut dimasukkan ke dalam autoclave. Rangkaian alat autoclave ditutup rapat. Gas $\mathrm{N}_{2}$ kemudian dimasukkan ke dalam autoclave hingga indikator tekanan menunjukkan angka $5 \mathrm{~kg} / \mathrm{cm}^{2}$. Setelah mencapai tekanan $5 \mathrm{~kg} / \mathrm{cm}^{2}$, valve yang mengarah ke tangki $\mathrm{N}_{2}$ ditutup, sedangkan purge valve dibuka. Kemudian purge valve ditutup dan autoclave kembali diisi dengan gas $\mathrm{N}_{2}$. Siklus pencucian gas dalam autoclave menggunakan $\mathrm{N}_{2}$ ini dilakukan sebanyak 3 kali. Setelah pencucian, gas $\mathrm{N}_{2}$ dimasukkan ke dalam autoclave sampai tekanan awal $10 \mathrm{~kg} / \mathrm{cm}^{2}$. Autoclave dan pengaduk dinyalakan dengan suhu operasi diatur $200^{\circ} \mathrm{C}$. 
Tekanan dan suhu diamati dengan interval waktu 5 menit sebagai data profil suhu selama proses. Setelah mencapai suhu operasi, pemanasan ditahan selama 30 menit dan dilanjutkan dengan proses pendinginan sampai suhu lingkungan. Langkah percobaan yang sama dilakukan untuk temperatur $240^{\circ} \mathrm{C}$ dan $270^{\circ} \mathrm{C}$.

\subsubsection{Tahap Pengeringan}

Slurry dari proses hydrothermal disaring menggunakan kertas saring, corong Buchner dan pompa vakum. Padatan yang diperoleh kemudian dioven pada $110^{\circ} \mathrm{C}$ selama 4 jam dan kemudian ditimbang sebagai berat produk. Produk yang diperoleh dianalisis kadar air, kadar abu, kadar kalium dan nilai kalor pembakaran. Cairan yang telah dipisahkan dari padatan dianalisis senyawa yang terkandung didalamnya menggunakan GC.

\subsubsection{Tahap Pengujian Ketahanan Kayu terhadap Rayap}

Mengacu pada standar ASTM D3345-74 (1980), enam buah sampel kayu bangkirai ( $2 \mathrm{~cm}$ x $2,5 \mathrm{~cm} \times 5 \mathrm{~cm}$ ) disiapkan untuk uji rayap. Semua sampel kayu direndam dengan produk cairan hydrothermal di temperatur ruangan selama 24 jam. Dilanjutkan dengan proses pengeringan yang dibiarkan dalam kondisi ruangan sampai diperoleh berat kayu yang konstan. Ketahanan kayu terhadap rayap dilakukan dengan menempatkan 50 ekor rayap di dalam wadah berbentuk tabung dari plastik (diameter $20 \mathrm{~mm}$ dan tinggi $45 \mathrm{~mm}$ ) yang ditempelkan di atas sampel kayu serta diisi 1 gram pasir kering di dalamnya. Bagian atas silinder ditutup dengan kertas Whatman 42,5 mm untuk mempertahankan humidity. Pengujian ini dilaksanakan selama 3 minggu dengan kondisi operasi dijaga pada suhu ruangan dan berada di ruangan yang gelap. Aktivitas rayap pada masing-masing botol diamati serta pada akhir pengujian, mortality rating dihitung dengan mengamati jumlah kematian rayap setiap minggunya.

\subsection{Analisis Data}

\subsubsection{Analisis Proksimat}

Analisis proksimat yang dilakukan adalah analisis kadar air, kadar abu dan nilai kalor. Analisis tersebut dilakukan di Laboratorium Penelitian dan Pengujian Terpadu, Universitas Gadjah Mada.

\subsubsection{Analisis mineral}

Analisis mineral yang dilakukan adalah analisis kadar kalium menggunakan metode Atomic Absorption Spectrophotometer (AAS). Analisis AAS dilakukan di Laboratorium Penelitian dan Pengujian Terpadu, Universitas Gadjah Mada.

\subsubsection{Perhitungan Produk Hydrothermal}

Perhitungan terkait produk hydrothermal dilakukan dengan Persamaan (1) dan Persamaan (2).

Yield $=\frac{\text { Berat produk }}{\text { Berat sampel }} \times 100 \%$

Energy densification ratio $=\frac{\text { Kalor pembakaran produk }}{\text { Kalor pembakaran sampel }}$

2.4.4 Analisis Produk Cairan

Cairan yang telah dipisahkan dari padatan dianalisis dengan menggunakan Gas Chromatography- Mass Spectrophotometer (GCMS) dan dilakukan pula uji $\mathrm{pH}$.

\section{Hasil dan Pembahasan}

Hydrothermal treatment menyebabkan degradasi termal dari suatu bahan organik. Ikatan fisik dan kimia dari suatu material mengalami kerusakan, sehingga makromolekul seperti selulosa, hemiselulosa, dan lignin pada bahan baku akan terurai menjadi molekul-molekul yang lebih sederhana dengan berat molekul lebih kecil. Molekul-molekul ini ada yang terlarut dalam liquid maupun terdegradasi menjadi gas. Sedangkan sisa sampel biomassa akan terambil sebagai biochar. Komposisi kandungan yang dapat diperoleh dari proses ini, akan berbedabeda seiring dengan kenaikan suhu proses. Oleh karena itu, pengamatan pada kondisi operasi dilakukan untuk mengetahui fenomena yang terjadi selama proses berlangsung.

Gambar 2 menunjukkan perubahan suhu dan tekanan selama proses hydrothermal treatment. Berdasar Gambar 2, kecenderungan perubahan 
tekanan pada autoclave sebanding dengan perubahan suhu yang masing-masing ditunjukkan pada pressure gauge dan thermocouple sebagai sensor. Walaupun demikian, pengendalian suhu oleh on-off controller belum bekerja dengan baik. Hal ini terlihat dari masih terjadinya offset yang cukup signifikan dari set-point. Akibatnya suhu selama proses tidak stabil pada suhu operasi yang diinginkan.

Produk proses hydrothermal berupa padatan dan cairan dianalisis untuk mengetahui properties produk. Hasil analisis produk padatan disajikan pada Tabel 1.

Secara umum, proses hydrothermal menurunkan kadar air dan kadar kalium. Tabel 1 menunjukkan bahwa kadar kalium mengalami penurunan. Hal ini menunjukkan terjadinya leaching mineral dari bahan baku selama proses. Terlihat pula pada Tabel 1 bahwa proses ini meningkatkan nilai kalor (heating value) dari biomassa. Nilai kalor padatan meningkat seiring dengan meningkatnya suhu reaksi yang digunakan. Terjadinya kenaikan nilai kalor merupakan hasil dari meningkatkan persentase karbon dalam bahan, yang ditandai dengan berkurangnya kandungan oksigen dalam sampel. Nilai kalor tertinggi dihasilkan pada suhu $270^{\circ} \mathrm{C}$, yaitu 5.265,60 kal/g atau setara dengan 22,02

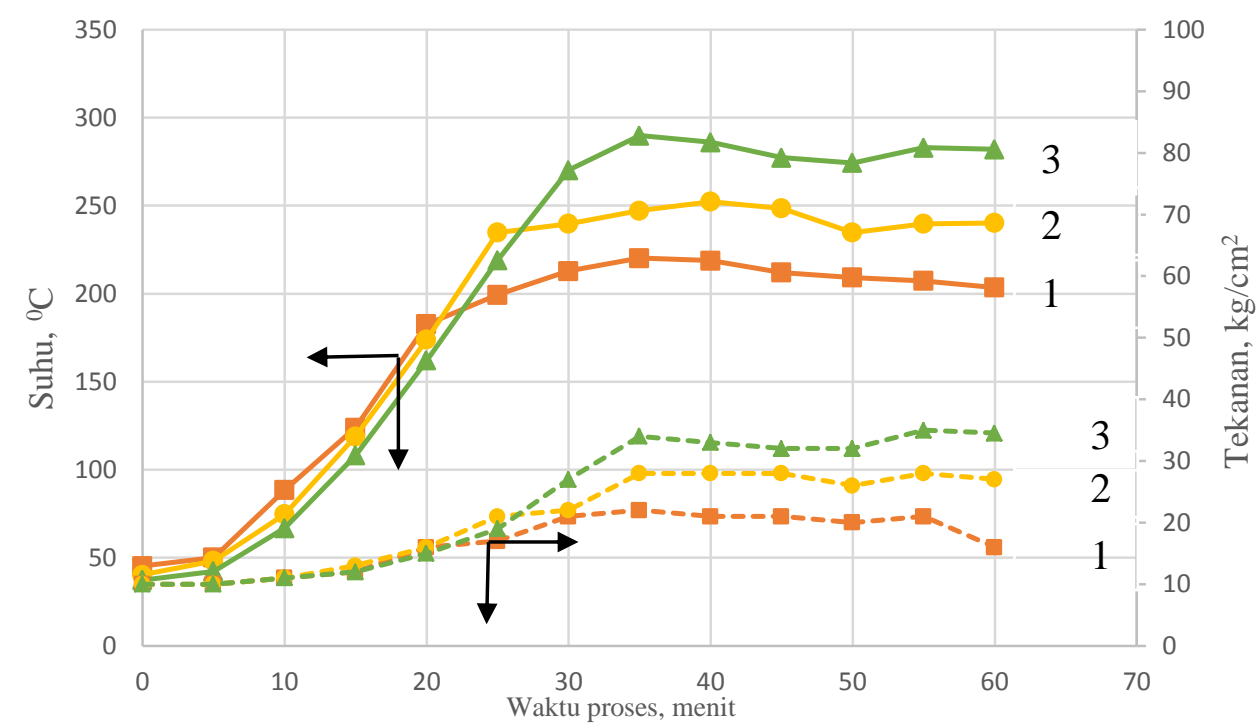

Gambar 2. Profil suhu dan tekanan hydrothermal treatment tongkol jagung $\left(1200^{\circ} \mathrm{C}, 2240^{\circ} \mathrm{C}, 3270^{\circ} \mathrm{C}\right)$

Tabel 1. Data hasil analisis bahan baku dan biochar pada berbagai variasi suhu

\begin{tabular}{lcccc}
\hline & & \multicolumn{3}{c}{ Suhu } \\
\cline { 3 - 5 } & Bahan Baku & $200{ }^{\circ} \mathrm{C}$ & $240{ }^{\circ} \mathrm{C}$ & $270{ }^{\circ} \mathrm{C}$ \\
\hline Kadar air, \% & 12,09 & 3,44 & 4,65 & 4,5 \\
Kadar abu, \% & 2,53 & 0,59 & 0,42 & 0,81 \\
Nilai kalor, kal/g & $3.873,13$ & $4.684,13$ & $4.929,42$ & $5.265,60$ \\
Kadar Kalium, mg/kg & $6.500,46$ & $1.536,55$ & $1.421,62$ & $1.475,29$ \\
\hline
\end{tabular}




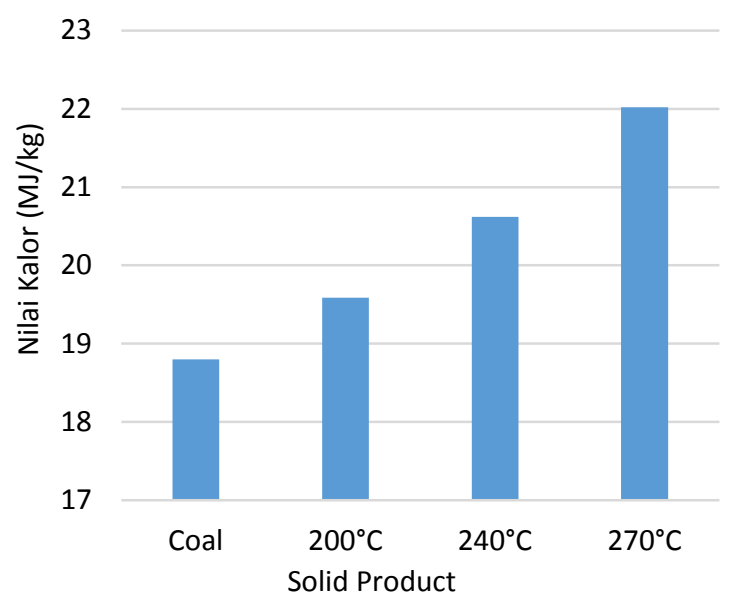

Gambar 3. Perbandingan nilai kalor batubara (International Energy Agency, 2016) dengan solid product hydrothermal treatment pada berbagai temperatur

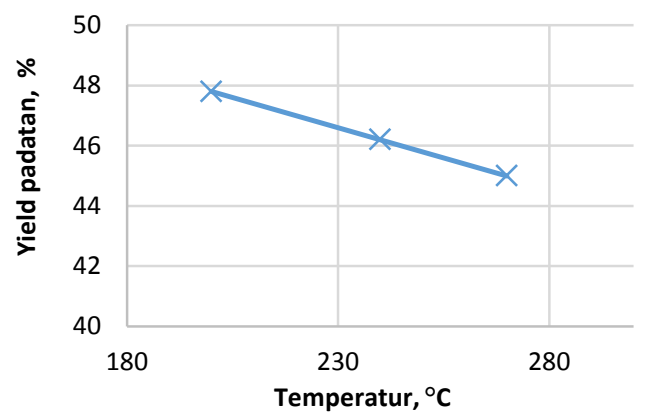

(a)

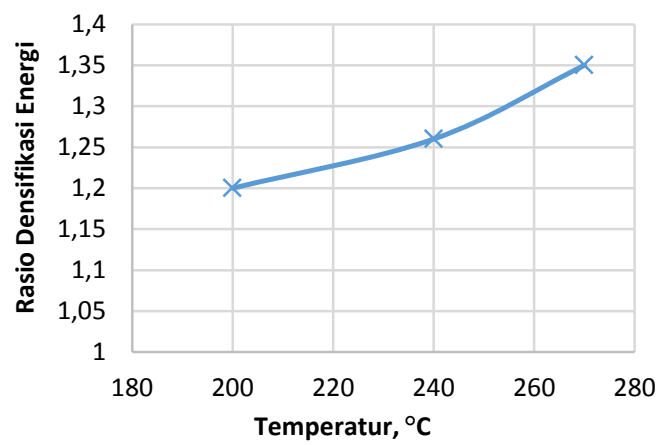

(b)

Gambar 4. (a) Hubungan temperatur dengan yield padatan, (b) Hubungan temperatur dengan rasio densifikasi energi

Gambar 3 menunjukkan bahwa produk hydrothermal memiliki nilai kalor yang lebih tinggi daripada batubara yang umum digunakan pada saat ini. Hal ini menguntungkan, karena pengunaannya yang kian meningkat setiap tahunnya. Solid product yang belum dilakukan briquetting memiliki efisiensi thermal yang lebih rendah (Grover dan Mishra, 1996), namun ukuran yang terlalu besar justru dapat memperlambat proses pembakaran (Sadaka, 2010).

Karakteristik produk padat dideskripsikan pada Gambar 4. Temperatur operasi memiliki pengaruh yang cukup signifikan terhadap yield padatan dan rasio densifikasi energi.

Dari Gambar 4(a) terlihat bahwa kenaikan temperatur menyebabkan penurunan yield padatan. Hal ini disebabkan karena sebagian besar makromolekul telah terdekomposisi menjadi molekul sederhana baik di fase cair maupun fase gas. Dari Gambar 4(b) dapat dilihat bahwa seiring dengan kenaikan temperatur terjadi kenaikan nilai kalor pembakaran yang dinyatakan dalam energy densification, yaitu perbandingan kalor bakar produk dan kalor bakar mula-mula. Rasio densifikasi energi terbesar diperoleh pada suhu proses $270^{\circ} \mathrm{C}$.

Melalui proses hydrothermal, bahan baku terdegradasi menjadi molekul kecil dan melarut dalam liquid. Gambar 5 menunjukkan hasil analisis GC-MS produk cair.

Dari hasil analisis pada Gambar 5 dapat dilihat bahwa produk cair mengandung berbagai senyawa organik. Gambar 5 menunjukkan bahwa $\mathrm{N}, \mathrm{N}$-dimethyl formamide dan furfural merupakan 2 komponen yang mendominasi pada berbagai variasi temperatur diikuti oleh ethyl-cyclopentane dan cycloheptane. Komponen furfural paling banyak dihasilkan pada variasi suhu $240^{\circ} \mathrm{C}$ mengindikasikan dekomposisi hemiselulosa secara optimum terjadi pada temperatur tersebut. Hal yang cukup berbeda adalah adanya kandungan 9-Octadecenoic acid dan komponen ester yang cukup tinggi pada variasi suhu $200^{\circ} \mathrm{C}$. Komponen ini memiliki kegunaan sebagai instektisida dan sebagai anti jamur. Selain itu, terdapat minor acidic component yang diwakili dengan munculnya benzoic acid pada suhu $200^{\circ} \mathrm{C}$ saja. 

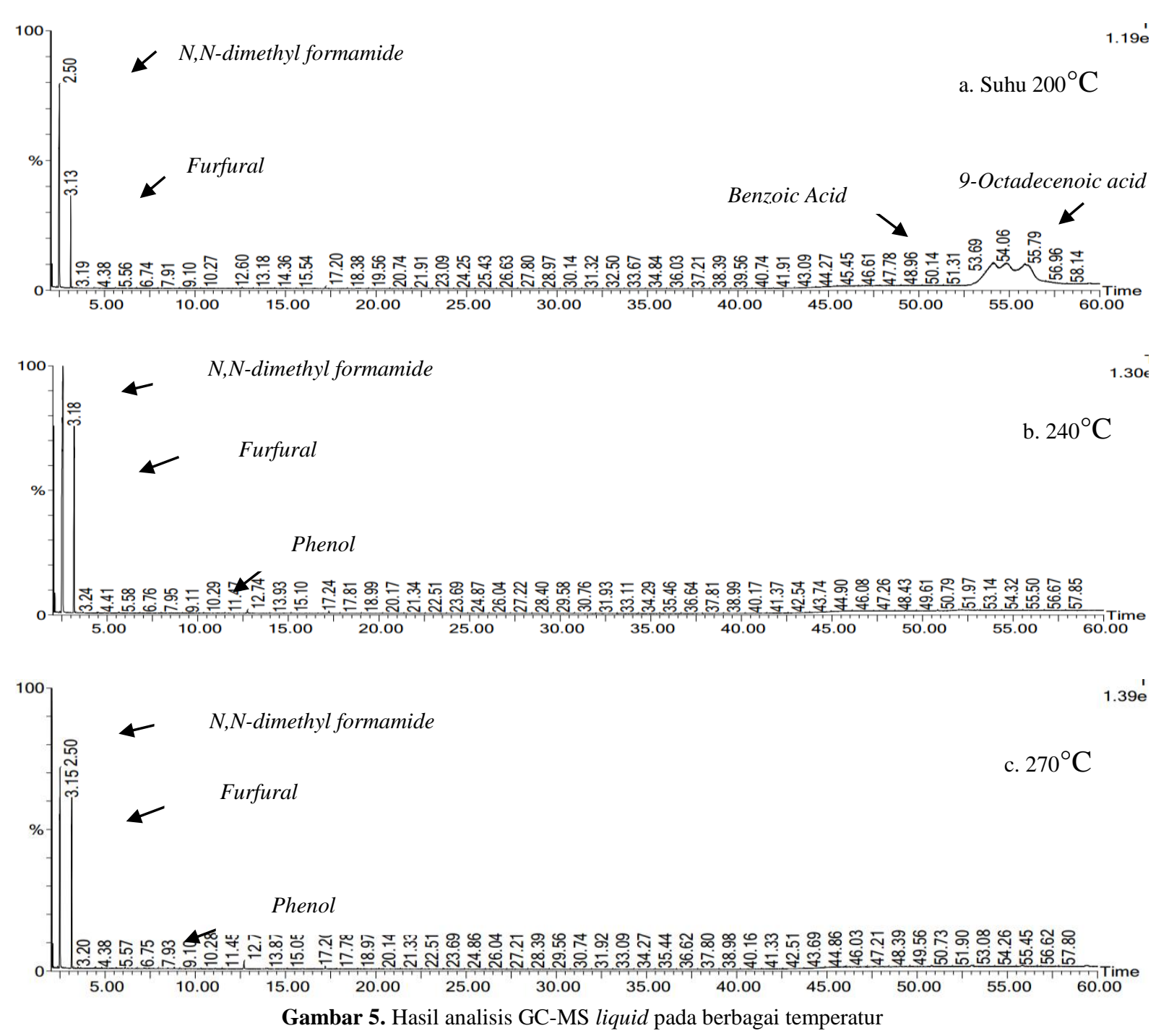

Kandungan carbonyl paling banyak ditemui pada suhu $200^{\circ} \mathrm{C}$. Komponen ini memiliki kegunaan sebagai penghasil aroma yang bersifat penolak serangga. Hal ini ditandai dengan warna coklat yang paling gelap yang dijjumpai pada produk cair dengan variasi suhu $200^{\circ} \mathrm{C}$. Senyawa phenol dan 2-methoxy phenol yang berfungsi sebagai anti-mikroba tidak terdapat pada variasi suhu $200^{\circ} \mathrm{C}$, dan mengalami peningkatan jumlah pada suhu $240^{\circ} \mathrm{C}$ dan $270^{\circ} \mathrm{C}$. Hal ini mengindikasikan adanya dekomposisi lignin yang optimum pada temperatur mendekati $270^{\circ} \mathrm{C}$.

Hasil yang diperoleh dalam penelitian ini telah sesuai dengan beberapa penelitian sebelumnya seperti yang dilakukan oleh (Kalderis dkk, 2014) yang menggunakan berbagai biomassa seperti sekam padi dengan cairan yang dihasilkan mengandung furfural, phenol dan senyawa organik lainnya. Akan tetapi, pada penelitian ini tidak terdapat asam asetat yang biasanya ditemui pada produk cair biomassa lain.

Organic preservatives yang baik memiliki kisaran $\mathrm{pH}$ 1,5-3,7. Pada kisaran tersebut, mikroba tidak bisa hidup dan berkembang biak sehingga pertumbuhan mikroba terhambat. Produk cair yang diperoleh dalam penelitian ini memiliki nilai $\mathrm{pH}$ pada variasi suhu $200^{\circ} \mathrm{C}$, $240^{\circ} \mathrm{C}$ dan $270^{\circ} \mathrm{C}$ berturut-turut adalah 3,$5 ; 5,2$ dan 5,4 .

Produk cair penelitian ini mengandung senyawa $N, N$-dimethyl formamide yang umumnya digunakan sebagai pestisida pada tanaman namun memiliki tingkat toksisitas yang cukup tinggi yang dapat menyebabkan kemandulan sehingga berbahaya dan kurang cocok jika digunakan sebagai pengawet perabot 
rumah tangga (anti-rayap). Dari hasil analisis kandungan produk cair tersebut, kecil kemungkinannya dapat dijadikan sebagai organic preservatives. Oleh karena itu, dilakukan uji kualitas dengan uji menggunakan rayap untuk melihat secara langsung aplikasinya.

Tabel 2. Persentase mortalitas rata-rata rayap tanah setelah pengumpanan selama 16 hari dengan menggunakan liquid hydorthermal

\begin{tabular}{cccccc}
\hline \multirow{2}{*}{ Jenis Sampel } & \multicolumn{3}{c}{ Mortalitas (\%) } & $\begin{array}{c}\text { Mortality } \\
\text { Rating* }\end{array}$ \\
\cline { 2 - 4 } & Minggu I & Minggu II & Minggu III & Slight \\
\hline Kontrol & 0 & 4 & 6 & Slight \\
$200^{\circ} \mathrm{C}$ & 4 & 12 & 14 & Slight \\
$240^{\circ} \mathrm{C}$ & 2 & 6 & 8 & Moderate \\
$270^{\circ} \mathrm{C}$ & 6 & 8 & 10 &
\end{tabular}

*) Mortality rating: 0-33\%, slight; 34-66\%, moderate; 67$99 \%$, heavy and $100 \%$, complete.

Dari hasil mortalitas pada Tabel 2, setelah dilakukan uji selama 16 hari diketahui bahwa adanya produk cair dapat memberikan efek pengawetan terhadap kayu dari segi kematian rayap. Jumlah rayap yang mati mengalami kenaikan seiring dengan bertambahnya hari. Pada sampel kontrol (untreated) kematian rayap cenderung lambat, sedangkan pada sampel variasi $200^{\circ} \mathrm{C}$ terdapat kematian rayap yang cukup signifikan jika dibandingkan dengan variasi temperatur yang lain. Hal ini disebabkan produk cair pada temperatur $200^{\circ} \mathrm{C}$ memiliki tingkat keasaman yang lebih tinggi jika dibandingkan dengan variasi yang lain. Adanya 9-Octadecenoic acid membuktikan bahwa produk cair dapat menjadi insektisida terhadap rayap. Pada variasi temperatur $270^{\circ} \mathrm{C}$ meskipun nilai keasamannya cenderung rendah, adanya phenolic compound yang cukup tinggi mampu menghambat pertumbuhan organisme.

\section{Kesimpulan}

Kesimpulan yang dapat diambil dari penelitian ini adalah proses hydrothermal mampu mengurangi kadar air dan kadar kalium. Selain itu, semakin tinggi temperatur proses, nilai kalor produk padat serta rasio densifikasi energi mengalami kenaikan. Adapun produk padat memiliki nilai kalor yang lebih besar dari batubara hingga mencapai 4-17\%. Perlakuan produk cair pada kayu dengan penambahan rayap berpengaruh terhadap pengawetan kayu. Hal ini ditandai dengan meningkatnya jumlah kematian rayap terhadap waktu dan variasi temperatur $200^{\circ} \mathrm{C}$ memberikan hasil yang optimum. Terdapat beberapa saran yang dapat diberikan untuk penelitian selanjutnya adalah dilakukan proses bricquetting dari produk padat yang dihasilkan, dilakukan analisis ultimate pada bahan baku dan produk padat untuk mengetahui komparasinya dengan batu bara secara rinci sehingga dapat dilakukan analisis Van Krevelen Diagram. Selain itu, untuk memastikan toksisitas pada produk cair sebaiknya dilakukan uji toksisitas dengan menggunakan metode BLST.

\section{Daftar Pustaka}

Agata, G.A., 2016. Naskah Seminar: Pengaruh Suhu pada Proses Upgrading Berbagai Jenis Biomassa dengan Hydrothermal Treatment. Departemen Teknik Kimia, Universitas Gadjah Mada: Yogyakarta.

ASTM, 1980. Standard Test Method Laboratory Evaluation of Wood and Other Cellulosic Materials for Resistance to Termites. American Society for Testing and Material ASTM D3345-74, Philadelphia, PA.

ASTM, 2013. Standard Practice for Proximate Analysis, American Society for Testing and Material ASTM D3172-12, West Conshohocken, PA.

Child, M., 2014, "Industrial-Scale Hydrothermal Carbonization of Waste Sludge Materials for Fuel Produsction", Lappeeranta University of Technology, Finlandia.

Food And Agriculture Organization of The United Nations (FAO). 2010 .Global Forest Resources Assessment 2010 Country Report, Forest Resources Divison.FAO, Roma, Italia.

Grover, P.D. \& Mishra, S.K., 1996. Regional Wood Energy Development Programme In Asia Gep / Ras / 154 / Net Biomass Briquetting: Technology And Practices. (46). International Energy Agency, 2016. World Energy Outlook. OCED, Paris.

Kalderis, D. dkk, 2014. Characterization of hydrochars produced by hydrothermal 
carbonization of rice husk. Solid Earth, 5(1), pp.477-483.

Obernberger, I., Brunner, T. and Bärnthaler, G., 2006. Chemical properties of solid biofuels significance and impact. Biomass Bioenergy, 30(11), pp.973-982.

Richana, N.U.R., 2010. Saccharification Of Corncob Using Cellulolytic Bacteria For Bioethanol Production., 17(2), pp.105-114.

Sadaka, S., 2010. Gasification, Producer Gas, and Syngas. Agricultural and Natural Resources, University of Ankansas, USA.

Yatagai M. et.al, 2004. Termiticidal activity of wood vinegar, its components and their homologues. J Wood Sci2002;48: 338-342.
Yuliansyah, A.T. et al., 2010. Production of Solid Biofuel from Agricultural Wastes of the Palm Oil Industry by Hydrothermal Treatment. Waste and Biomass Valorization, 1(4), pp.395-405.

Yuniningsih, S., 2014. Utilization of Various Types of Agricultural Waste Became Liquid Smoke using Pyrolysis Process., 28, pp.6066. 